\title{
The "Black" Side of the Story: History Rewriting in Andrea Levy's Small Island
}

\author{
CAI Xiaoyan \\ Faculty of English Culture and Language, Guangdong University of Foreign Studies, China \\ Received: September 20, $2021 \quad$ Accepted: October 6, $2021 \quad$ Published: January 31, 2022
}

The research project entitled "City Writings of Hanif Kureishi" is supported by Guangdong University of Foreign Studies with No. 19QN44.

To cite this article: CAI Xiaoyan. (2021). The "Black" Side of the Story: History Rewriting in Andrea Levy's Small Island. Asia-Pacific Journal of Humanities and Social Sciences, 1(4), 019-027, DOI: 10.53789/j. 1653-0465. 2021.0104.003. p

To link to this article: https://doi. org/10.53789/j. 1653-0465.2021.0104.003.p

\begin{abstract}
The attempt to recover the history of Black people and integrate it into the narratives on Britain has underscored black British writing since the 1990s. Andrea Levy's novel Small Island retells the British history during and after the Second World War by inscribing the previously marginalized or obliterated stories of the Afro-Caribbean servicemen and the various black-white encounters and interactions. By recuperating the experience of the black diaspora and integrating it into an otherwise homogeneously white British history, Levy participates in the general effort of the black British writers to redefine Britishness to claim a place in it. Thus it helps construct a more inclusive and relational version of British history, challenging and transforming the exclusively-white configuration of Britishness.
\end{abstract}

Keywords: Small Island; Second World War; identity

Notes on the contributor: CAI Xiaoyan is an associate professor of English Literature at the Faculty of English Language \& Culture in Guangdong University of Foreign Studies, China. Her research interest lies in contemporary British fiction and diaspora studies. Her email address is caixiaoyan@ gdufs. edu.cn.

\section{Introduction}

History has been a recurrent preoccupation in black British literature ${ }^{1}$, which is especially evident in the black British writers of a new generation. Unlike their literary predecessors who often write about their family places of origin, the young black writers tend to explore multi-ethnic Britain. As Britons, they are born and bred. They relate to Britain as their home country and view themselves not as outsiders but as "critical insiders" (Wambu 1998: 28). As Levy asserts through her character's voice: "I had grown up in its English ways. I could confront it, rail against it, fight because it was mine - a birthright" (1994: 88). Nevertheless, there are still some sectors of British society who insist on viewing "blackness and Britishness [as] mutually incompatible 
identities", and refuse to accept them as fully British (Gilroy 1987: 28). In order to justify their sense of belonging, they rewrite British history by recuperating the experiences of the black diaspora in the country, which had been marginalized or even obliterated in traditional narratives.

This historical consciousness greatly informs the writing of Andrea Levy. Her novels always engage topics related to the Jamaican diaspora in British history, bringing forward the silenced yet significant voices such as those of the Caribbean slaves. Her fourth novel Small Island looks back on the Windrush generation ${ }^{2}$ and rewrites the part of British history that deals with its multicultural beginnings. Since its publication in 2004, the novel has achieved fame both nationally and internationally by garnering various literary awards and become a key site for "reflecting on the recent past of the country, and on the place of the Afro-Caribbean diaspora in contemporary British identity" (P. A. Sell 2012: 99). By looking into the details of its representation of the historical events, this paper argues that Small Island rewrites the British history during and after the Second World War by retelling the previously marginalized or obliterated experiences of the Afro-Caribbean servicemen and depicting the various black-white encounters and interactions, thus it helps construct a more inclusive and relational version of the British history, challenging and transforming the exclusively white configuration of Britishness.

\section{Recovering Earlier Black Presences: Afro-Caribbean in the Second World War}

Opening with a "Prologue", the novel is then made up of nine parts alternately titled "1948" and "Before": "1948" is the year that inaugurates Britain's multicultural era whereas "Before" is a vague time-span that precedes 1948. Each of the nine parts comprises a number of chapters, each of which, titled with the narrator character's name, tells his/her story in first-person perspective. Thus, the novel braids together the overlapping narratives of four major characters: Gilbert, a Jamaican who joins the Royal Air Force in the Second World War and moves to Britain afterwards. His wife Hortense comes to join him in 1948, their white English landlady Queenie, and her husband, Bernard. With these alternatives, multiple voices, Small Island confronts the singular and linear representation of the experience of migration and empire and instead emphasizes "a plurality of moments, locations, and perspectives" (Ellis 2012: 71).

Through the word "Before", Levy calls our attention to a "pre-history" prior to 1948. While the term "1948" evokes the year of the Windrush arrival, the word "Before" elicits temporal elusiveness, yet this deliberately undetermined term shows that Levy looks at the Windrush arrival not as an abrupt and disruptive moment but as part of a more extended history. This indicates a more expansive view of the black presence, confronting the official formulation of the Windrush arrival as the unequivocal origin of black Britain.

On 22nd June 1948, the SS Empire Windrush docked at Tilbury in London and disembarked 492 West Indian emigrants, initiating post-war mass immigration to Britain. Britain's mainstream media have since identified this episode as the inaugural moment of its multiculturalism and "a black British past" (Procter 2000: 1). The reporting of the event is so ubiquitous that the Windrush has become one of the most popular cultural symbols in Britain. But the repeated inscription of the Windrush across various cultural forms does not respond to a history of complex migrations but to "a need to recognize this event as a revolutionary rupture in a national identity imagined as homogeneous" (Mead 2009: 137). The earlier black presences have usually been erased or down- 
played to make people believe that the black presence in Britain is a recent phenomenon and that the arrival of black people in Britain is "an illegitimate intrusion into a vision of authentic British national life that, prior to their arrival, was as stable and peaceful as it was ethnically undifferentiated" (Gilroy 1987: 7).

But as Deirdre Osborne has pointed out, "multiculturalism is not simply a twentieth-century phenomenon in the British Isles. The circulation of people and materials to and from Britain's shores $[\ldots]$ means it has never been a mono-racial enclave. However, a conglomerate of various ethnic groups" (2016: 2-3). Historians have proved a long history of pre-war black Britain, including, as Tim Brennan has neatly summarized, "a now fairly well-known tale about the Moorish soldiers of Hadrian's army, the African entertainers in the Tudor court, the freedmen of Dr Johnson's era, or the writers of the great emancipation autobiographies" (1990: 7). Researches into these earlier black presences have repeatedly shown that black people remain an intrinsic part of British history, contributing to the dismantling of the traditional version of British history as a culturally and ethnically homogeneous one. What was also helpful about such scholarship was that it "offered a convincing counter-argument", telling young blacks that they had not only "a legal right" to be in Britain, but "a historical one" (Sandhu 2003: 284). The sense of righteousness that these historical facts offered informed the work of many young black writers.

Since the 1990s, black British writers of a younger generation such as BernardineEvaristo, Caryl Phillips, David Dabydeen and S. I. Martin have all created historical novels based on academic researches into the micro -histories of black Britain. This is also the case with Andrea Levy, who created Small Island by drawing inspirations from her uncle's experiences in the Royal Air Force and incorporates insights gained from such important histories as those collated in Mike Phillips and Trevor Phillips's Windrush: The Irresistible Rise of Multi-Racial Britain (1998) and Robert N. Murray's Lest We Forget - The Experience of World War II West Indian Exservice Personnel (1996). ${ }^{3}$ Thus, Small Island can be read alongside the other historical novels published by the black British writers, and its revisit of the Second World War can be seen as part of a more general effort to recuperate a black British past prior to the Windrush arrival and to integrate it into the main narrative of British social and historical life.

Gilbert's war experience testifies to the fact that men and women from Caribbean colonies widely participated in the Second World War. As shown in a scene describing the military parade, thousands of Jamaican volunteers march in the Capital City of Kingston before going to the war, who, as noticed by Hortense, include men of all ages and from all walks of life:

But close to this fighting machine was merely composed of line after line of familiar strangers. Fresh young boys who had only just stopped larking in trees. Men with skin as coarse as tanned leather, whose hands were accustomed to breaking soil. Big-bellied men who would miss their shine even through battle. It seemed that all the dashing, darting and some of the daft of the island walked there before me. (Levy 2004: 71)

As black soldiers, they have to face more difficulties than their white counterparts: not only the hardships of life and the dangers of the war- "guns, air-raids and bully-beef $[\ldots]$ the wintry winds that blew across English moors" (Levy 2004: 89), but also the racial prejudice and attack by the white. But they endure all these with firm faith to save their "mother country".

Gilbert's account of the war serves as a thread linking all the stories of his fellow countrymen at home and a- 
broad, showing their involvement with and contribution to the war. Parallel to the volunteers' experience at the front is the story of Jamaican people back home who do what they can to raise money for the British army. In the epilogue of the novel, Levy quotes a line from Winston Churchill's "Battle of Britain" speech made in 1940, "Never in the field of human conflict has so much been owed by so many to so few", and through this ambivalent message, she tries to honor all the Afro-Caribbean who served the British empire in its hour of need.

The incorporation of the black narrative voice, a perspective that is rarely heard in Britain's historical and fictional narratives, enables a more "inclusive portrayal of the Second World War" (Weedon 2004: 40), giving us new insights into that part of the British past. By showing black people's experience in the war, the novel foregrounds a less well-known aspect of history that has been usually downplayed or obliterated in history books and documents. It also offers a counter-history to the official narratives about the battle of Britain as "a white man's war" by showing the collaboration between the white and black and therefore changes the way how the war should be remembered.

\section{The "Contact Zones": Revealing the Shared History of Black and White}

Levy has repeatedly stated that one purpose of her writing is to recover the history of the Caribbean in Britain and to reveal that their history is an indispensable part of the British history: "Britain owes an enormous historical debt to the other countries of the Commonwealth and I hope that through literature our shared history can be better understood" (qt. in Muñoz-Valdivieso 2010: 163). In this novel, the shared history between the white and black is embodied in their various moments of encounters, specifically, the Empire Exhibition, ${ }^{4}$ the war and the house of Queenie. These "Contact Zones", ${ }^{5}$ in which different cultures meet and merge, blurring boundaries and establishing complex connections, invite us to see British history as an inclusive site of multicultural convergence.

The first contact zone is the 1924 British Empire Exhibition visited by young Queenie represented in the novel's prologue. The exhibition is at once a celebration of the power and riches of the empire and a staged spectacle of alterity, where she is first confronted with cultural differences. Her brief yet impressive interaction with the African man "not only structures her personal narrative but also tells part of a greater story of historical encounters between Britain and its empire" (Ellis 2012: 70).

Together with the displays of the raw materials and the native architectural miniatures, the indigenous peoples, wearing exotic costumes and decorations, are also made part of the show. All the things displayed at the exhibition remind the readers of the history of colonization behind. The relationship between the white visitors and the local peoples on display re-enacts the relationship between the colonizer and the colonized. And the arrogance and ignorance of the white visitors inform not only the previous colonial encounters but also their future encounters following the decline of the empire.

There, for the first time in her life, Queenie comes upon a black man from Africa whom she finds both exotic and attractive:

An African man. A black man who looked to be carved from melting chocolate. [... ] A monkey man sweating a smell of mothballs. Blacker than when you smudge your face with a sooty cork. The droplets of sweat on his forehead glistened and shone like jewels. His lips were brown, not pink like they should be, and they bulged like bicycle tires. His hair was woolly 
as a black shorn sheep. His nose, the squashed flat had two nostrils big as train tunnels. And he was looking down at me. (Levy 2004: 6)

To young Queenie, the African man is so strange that she has to understand him in terms of more familiar objects. But her depiction conveys her confused feelings of disgust and attraction since the things she thinks of are both ugly and beautiful. Besides, the language she uses is rather sensual. So in her eyes, the African man is not just an object of ridicule but an object of desire. This is more evident as she "feel [s] the blood rising in [her] face, turning [her] crimson" when the man shakes her hand and greets her with "clear English" (Levy 2004: 6). His polite manners also impress Queenie and contradict the stereotype of a black man in her mind.

This meeting serves several functions. Personally, it instills in young Queenie a curiosity and open-mindedness towards black people, which shapes her future "cosmopolitan inclusiveness" as the landlady who takes in black lodgers (Brophy 2010: 104). Her interest in the African man also predetermines her erotic relationship with the Jamaican pilot Michael Roberts who stays at her house for a few days while her husband is away at war. At the nation's level, her mixed feelings set the tone for "the moment when the nation itself will become a site of ongoing interracial and cross-cultural encounters" (Ellis 2012: 78).

Another "Contact Zone" is the Second World War. The novel's multi-layered narrative of the war, with each character's version intersecting with the others', gives the effect of "a culturally and ethnically diverse group pulling together" (Weedon 2004: 40). Involving people from the imperial center and its colonial territories, the war becomes a space where people of black and white form an alliance in fending off their common enemies, despite the ongoing interracial tensions.

It is true that the coming of the Caribbean volunteers sparks many conflicts. As revealed by Gilbert, while there is a war between Britain and the Nazis, he and his black mates are fighting another war - the war over racism. The black soldiers are not allowed to mix with their white counterparts, and they have to endure constant verbal attacks and unequal treatment from their white superiors. They try to resist them, only to find that their resistance leads to more violent eruptions. There is an incident where Gilbert resists a segregated seating plan in a local cinema and sets off a riot resulting in Queenie's father-in-law's death.

Notwithstanding these racial divides and hostilities, the Second World War appears a site of friendship and collaboration. The first meeting between Gilbert and Queenie during the war exemplifies these possibilities. When Gilbert finds and returns Queenie's lost father-in-law to her house, she returns his help with great hospitality. In their subsequent talk at the house, the host and the guest make each other laugh with their respective jokes. The shared sense of humor lays the foundation for their friendship and future encounters. What is more, welcome and encouragement are frequently shown to the Caribbean volunteers. In one instance, when the Yorkshire villagers see Gilbert and his black mates, they come up and shake their hands, saying: "We' re glad to have you here - glad to have ya" (Levy 2004: 138). So the Second World War, as summarized by Gilbert, is a time when black-white brotherhood is possible because they are "on the same side [...] fighting for empire, fighting for peace" (Levy 2004: 525).

Compared with the exhibition and the war, Bernard and Queenie's house on Nevern Street appears a more notable "Contact Zone" since it is the space where "the spectacle and trauma of a black-white encounter are most sensationally staged" (Procter 2003: 22). In a way, the house, an obvious trope of the deteriorating nation, dis- 
plays two sides of the immigrants' initial settlement. While their encounter with the landlord Bernard is full of conflicts and even violence, their relationship with the landlady Queenie is one filled with care and warmth. So the house is turned into a stage showing conflicts and hostilities, on the one hand, cooperation and friendship on the other.

Obviously, Queenie's image as a woman on her own taking in black tenants is an allusion to the elderly lady featured in Enoch Powell's notorious 1968 "Rivers of Blood” speech, in which he argues for an end to immigration and the repatriation of Black people. In his speech, he transforms a white woman's tense interaction with the Afro-Caribbean immigrants into a case of violence. The victimized lady too scared to go out, the aggressive and violent black immigrants, the closed door, and the broken windows, all these images are employed to create a picture of interracial tension and conflict.

But the story at Queenie's house rewrites the quoted incident in every aspect. First, Queenie reverses the image of the victimized landlady by enjoying her relationship with her tenants. Being kind and helpful, she is a strong woman respected and even awed by her tenants. The politeness of Gilbert and Hortense also contrasts with the rude behaviors of the black immigrants. And the door opening wide for the black immigrants offers a counter -image to the old lady's closed ones. In the novel's closing scene, Hortense helps Queenie give birth to her mixed-race baby conceived with Michael Roberts and agrees to adopt it as her son, implying the inseparable future of the two couples. The house is again turned into a contact zone signifying "intimacy, community, and a multiracial future" (Brophy 2010: 100).

\section{History Rewriting and Redefinition of Britishness}

In her essay "This is my England”, Levy makes a statement about her identity as fully English:

I am English. Born and bred, as the saying goes [...] England is the only society I truly know and sometimes understand. I don't look as the English did in the England of the 30s or before, but being English is my birthright. England is my home. An eccentric place where sometimes I love being English. (2000)

Unlike the previous generation of black writers who gained their British identity via Commonwealth status, the new black writers base their claim to British identity on Britain's place where they were born and bred. Nevertheless, some sectors of British society still see the black Britons as " "in' but not 'of' the nation” (qt. in Osborne 2016: 33 ). The intentional denial has resulted in the lack of representation of black Britons in British culture and history, leaving them painful in attempting to identify as British. This is a feeling explicitly expressed by the black British writers through the voice of their characters. Irie Jones, in Zadie Smith's White Teeth (2000), for example, laments: "There was England, a gigantic mirror, and there was Irie, without reflection" (2000: 266). The protagonist in Bernardine Evaristo's novel-in-verse Lara (1997) also points out the lack of public representations of her own people in the country: "I searched but could not find myself, /Not on the screen, billboards, books, magazines” (1997: 69).

Facing the "vexing questions" of belonging and identity, the black writers criticize the exclusive view on Britain on the one hand and try to redefine the notion of Britishness on the other. They use fiction to articulate 
the silenced voices and explore black experiences in British history to help construct a more "inclusive discourse of Britishness that acknowledges the multifaceted, complex and profound interconnections" between Britain and other cultures, especially those of her colonies (Weedon 2004: 27). The new formulated Britishness provides the black Britons with the basis for their confident identification with the country.

In Small Island, Levy recovers the Afro-Caribbean experience during and after the Second World War and portrays Britain as an open space where different cultures encounter and merge, and identities are reformed. Her reconceptualization of the British national identity comes with the climax when Queenie gives birth to a mixedrace child conceived with Michael Roberts, a Jamaican member of the RAF, with whom she has had a brief affair. The mixed-race baby, an obvious symbol of hybridity, suggests that British history can no longer be conceived as culturally homogeneous, and thus a new form of British identity should be forged.

Indeed, the identities of all four protagonists are far from fixed but under constant transformations throughout the novel. Gilbert, for example, undergoes incessant adjustments in his perception of the home country and the metropolis as well as in his cultural identifications. Before joining the British Air Force, Gilbert identifies with Jamaican culture and sees himself as a Jamaican. Yet the experience in the war changes his perception of his home country, the largestWest Indian island becomes a restrictive, stifling place: "I was a giant living on land no bigger than the soles of my shoes. Everywhere I turn I gaze at the sea. The palm trees that tourists thought rested so beautifully on every shore were my prison bars. Horizons my tormenting borders" (Levy 2004: 209). Being unable to return just to his home island, Gilbert migrated to England for more opportunities. But his romantic idealization of England as the loving, nurturing Mother shatters as he encounters its rundown and racist reality: "The filthy tramp [...] Ragged, old and rusty [...]. This stinking cantankerous hag. She offers you no comfort after your journey. No smile. No welcome" (Levy 2004: 139). Originally regarding himself as a British subject "coming home" to his Mother Country, Gilbert finds him rejected by the white English as an outsider. His frustration and identity crisis becomes even more severe as he is constantly confronted with hostility and discrimination in search of accommodation and work. In dealing with these situations, Gilbert tries to adjust his cultural identifications and his sense of belonging to the country, giving rise to the formation of a diasporic black identity. The lodging house where he and Hortense inhabit, a Contact Zone fraught with cross-cultural tensions and negotiations, becomes a space for his reassessment. It is a space of promise and security as the characters claim it and use it to maintain their dignity in facing discrimination. It is also a space of contestation where they negotiate the boundary and limit of diasporic living in the metropolis.

At the end of the story, as Gilbert and Hortense are moving into a different lodging house, Gilbert gives a speech showing his understanding of a British past: "Listen to me, man, we both just finish fighting a war-a bloody war-for the better world we can see [...] You and me, fighting for empire, fighting for peace [...] We can work together. Mr. Bligh. Youno see? We must” (Levy 2004: 525). Through her character's voice, Levy once again reviews the hybrid nature of British history by stressing the common experience of the black and white and the possible friendship between the two. The new understanding of British history, along with the birth of the mixed-raced baby, anticipates new forms of being British.

\section{Conclusion}

In conclusion, Andrea Levy unsettles a homogeneous view of British history and British identity by looking 
back at a crucial period in British history from the cross-cultural approach in her novel Small Island. The polyphonic work recovers the silenced black experience and offers a more inclusive version of British history. By showing the various black-white encounters and interactions, she depicts the nation in a relational and transnational approach. So the title of the novel "Small Island", an obvious allusion to John Donne's poem "No Man is an Island", warns us against the exclusive and narrow understanding of the nation. By alluding to both the British isle and Jamaican isle, it also hints at the relatedness of the two countries, reminding us that when we read the story of the former, we should remember that there is always the story of the latter.

\section{Note:}

${ }^{1}$ The term "black British literature" was originally designed to describe writing by authors based in Britain but with origins in former British colonies in Asia, Africa, and the Caribbean. However, the term has lost some of its early scopes and now conventionally refers to authors of African and Caribbean descent. See Bénédicte Ledent, "Black British Literature" in The Oxford Companion to English Literature (Oxford: Oxford University Press, 2009).

${ }^{2}$ The Windrush generation refers to the immigrants who came to work and stay in Britain from Caribbean countries between 1948 and 1971, following the implementation of The British Nationality Act 1948. The name derives from the ship SS Empire Windrush, the first of many ships to carry African-Caribbean migrants to Britain.

${ }^{3}$ In the acknowledgment of the novel, Levy listed all the books and documents that she has done research on.

${ }^{4}$ The 1924 British Empire Exhibition held in Wembley, London, was the largest exhibition ever staged, bringing together 58 different countries. Its official aim was to proclaim the economic importance of the empire to the Britons and to make the different races of the British Empire better known to each other. For more information, see J. M. Mackenzie, Propaganda and Empire: the Manipulation of British Public Opinion, 1880-1960 (Manchester: Manchester University Press, 1986).

${ }^{5}$ Contact Zone, as defined by Mary Louis Pratt, refers to the space of colonial encounters in which peoples geographically and historically separated come into contact with each other and establish ongoing relations, usually involving conditions of coercion, radical inequality, and intractable conflict. See Mary Louise Pratt, Imperial Eyes: Travel Writing and Transculturation (London: Routledge 1992).

\section{References}

Brennan, Tim. (1990). Writing from Black Britain. Literary Review, 1, 5-11.

Brophy, Sarah. (2010). Entangledgenealogies: white femininity on the threshold of change in Andrea Levy's Small Island. Contemporary Women's Writing, 2, 100-113.

Ellis, Alicia E. (2012). Identity ascultural production in Andrea Levy's Small Island. Enter Text, 69-83.

Evaristo, Bernardine. (1997). Lara. Tunbridge Wells: Angela Royal Publishing.

FUChanni. (2021). A study of Leslie Fielder's views of American novels in his cultural criticism. Asia-Pacific Journal of Humanities and Social Science, 1(3), 158-165.

Gilroy, Paul. (1987). There ain't no Black in the Union Jack: the cultural politics of race and nation. London: Hutchinson.

Levy, Andrea. (1994). Every light in the house burnin'. London: Headline Book Publishing.

Levy, Andrea. (2004). Small island. London: Headline Publishing Group.

Levy, Andrea. (2000). This is my England. The Guardian Weekend. Available Online: http://www. theguardian. com/books/ 2000/feb/19/society1 (accessed on December 15, 2018).

Mead, Mathew. (2009). Empire windrush: the cultural memory of an imaginary arrival. Journal of Postcolonial Writing, 2, 137149.

Muñoz-Valdivieso, Sofía. (2010). Africa in Europe: narrating Black British history in contemporary fiction. Journal of European 
Studies, 159-174.

Osborne, Deirdre. (2016). Introduction. In Deirdre Osborne (Ed.), The Cambridge companion to British Black and Asian literature. Cambridge: Cambridge University Press.

P. A. Sell, Jonathan. (2012). Metaphor and diaspora in contemporary writing. London: Palgrave Macmillan.

Procter, James. (2000). Writing Black Britain 1948-1998: an interdisciplinary anthology. Manchester: Manchester University Press.

Procter, James. (2003). Dwelling places: postwar Black British writing. Manchester: Manchester University Press.

Sandhu, Skuhdev. (2003). London calling: how Black and Asian writers imagined a city. London: Harper Collins Publishers.

Smith, Zadie. (2000). White teeth. London: Penguin Books.

SHANXinrong \& JIA Shaodong. (2021). Translation in English and Chinese idioms from metonymy. Asia-Pacific Journal of Humanities and Social Sciences, 1(2), 83-89.

Wambu, Onyekachi. (1998). Empire windrush: fifty years of writing about Black Britain. London: Victor Gollancz.

Weedon, Chris. (2004). Identity and culture: narratives of difference. Berkshire: Open University Press.

(Editor: Bonnie Wang) 